Available online on 15.03 .2020 at http://jddtonline.info
Open Access to Pharmaceutical and Medical Research
unrestricted non-commercial use, provided the original work is properly cited

Open Access

Research Article

\title{
Validation of Stability Indicating Method and Degradation Kinetic Study of Apremilast
}

\author{
Jitesha Patel, Parin Chokshi, and Rajashree Mashru* \\ Faculty of Pharmacy, G.H. Patel Building, Donor's Plaza, The M.S. University of Baroda, VADODARA, 390002, INDIA
}

\begin{abstract}
A novel stability indicating RP- HPLC method was developed for the estimation of Apremilast in bulk and marketed formulation. Separation was achieved by using Shimadzu HPLC Analytical Technologies Limited C18 (250 mm x $4.6 \mathrm{~mm}, 5 \mu \mathrm{m}$ ) as stationary phase. The optimized mobile phase consist of potassium dihydrogen ortho phosphate (pH-3.2): acetonitrile in ratio of 40:60 \% v/v with flow rate of $1 \mathrm{~mL} / \mathrm{min}$ by using methanol as diluent. Retention time of Apremilast was found to be $5.4 \mathrm{~min}$ which was estimated at wavelength $360 \mathrm{~nm}$. Linearity of Apremilast was observed in the concentration range of $50-400 \mu \mathrm{g} / \mathrm{mL}$ with $\mathrm{r}^{2}$ value of 0.9999 . Assay of Apremilast tablet was found to be $99.14-100.75 \%$. Stability indicating nature of RP- HPLC method was estimated by conducting degradation kinetic study. The forced degradation of Apremilast bulk indicate that degradation in acidic, alkali, oxidative and photolysis condition were found to be $21 \%, 6.5 \%, 25.7 \%$ and $3.9 \%$ re spectively. The kinetic study of apremilast in alkali degradation followed first order kinetic study. The result indicate that the developed RP-HPLC method is suitable for estimation of Apremilast in presence of degradant product. The above method was validated as per ICH guideline.
\end{abstract}

Keywords: Apremilast, RP-HPLC, Validation, Forced Degradation Study, Alkali Degradation Kinetic study

Article Info: Received 02 Jan 2019; Review Completed 10 Feb 2020; $\quad$ Accepted 24 Feb 2020; Available online 15 March 2020

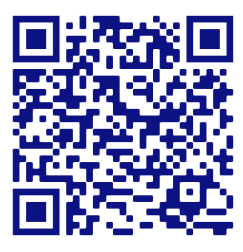

390002, INDIA

\section{Cite this article as:}

Patel J, Chokshi P, Mashru R, Validation of Stability Indicating Method and Degradation Kinetic Study of Apremilast, Journal of Drug Delivery and Therapeutics. 2020; 10(2):76-85 http://dx.doi.org/10.22270/jddt.v10i2.3964

*Address for Correspondence:

Rajashree Mashru, Faculty of Pharmacy, G.H. Patel Building, Donor's Plaza, The M.S. University of Baroda, VADODARA,

\begin{abstract}
Abbreviation:
APR : Apremilast

ICH : International Conference of Harmonization

RP-HPLC : High-performance liquid chromatography

\%RSD : Relative standard deviation
\end{abstract}

\section{INTRODUCTION:}

Apremilast is a phosphodiesterase 4 (PDE4) inhibitor, which mediates the activity of cyclic adenosine monophosphate (cAMP), a secondary messenger. The chemical name of APR is N- 2-[(1S)-1-(3-Ethoxy-4-methoxyphenyl)-2- (methyl sulfonyl) ethyl]-1, 3-dioxo-2, 3-dihydro- $1 \mathrm{H}$-isoindol -4-yl acetamide. Apremilast is indicated for the treatment of active psoriatic arthritis in adults, for the treatment of active moderate to severe psoriatic arthritis [1]. In July 2019, apremilast was granted a new FDA approval for the treatment of oral ulcers associated with Behcet's disease, an autoimmune condition that causes recurrent skin, blood vessel, and central nervous system inflammation [2]. This method aimed to validate the developed RP- HPLC method for determination of apremilast drug as per the ICH guideline. There are many Analytical method like U.V ISSN: 2250-1177
Spectrophotometric methods[3], HPLC methods[4] and Stability indicating RP-HPLC[5] are reported for determination of APR but there were no reported stability indicating RP-HPLC method along with degradation kinetic study for APR. Accordingly it was found that present research study has some extra advantages to develop and validate Stability indicating method for determination of APR in the presence of degradant products and to perform degradation kinetic study of APR.<smiles>CCOc1cc(C(CS(C)(=O)=O)N2C(=O)c3cccc(NC(C)=O)c3C2=O)ccc1OC</smiles>

Figure: 1 Chemical structure of APR [6] 


\section{MATERIALS AND METHODS}

Instrumentation: Shimadzu HPLC system with UV Detector, UV Visible spectrometer, $\mathrm{pH}$ meter, electronic balance.

Chromatographic condition:

Table: 1 Chromatographic Condition

\begin{tabular}{|l|l|}
\hline Parameter & Chromatographic conditions \\
\hline Instrument & Shimadzu LC20A \\
\hline Column & $\begin{array}{l}\text { Analytical Technologies Limited C18 } \\
\text { column(250 mm x 4.mm,5 } \mu \mathrm{m})\end{array}$ \\
\hline Flow rate & $1 \mathrm{~mL} / \mathrm{min}$ \\
\hline Detection wavelength & $360 \mathrm{~nm}$ \\
\hline Injection volume & $20 \mu \mathrm{l}$ \\
\hline Run time & 10 min \\
\hline Temperature & Ambient \\
\hline Mobile phase & potassium dihydrogen \\
orthophosphate: Acetonitrile(40:60) \\
\hline Diluent & $90: 10($ methanol:DMSO) \\
\hline
\end{tabular}

\section{Mobile phase preparation:}

Buffer for mobile phase: Phosphate buffer $(50 \mathrm{mM})$ prepared by dissolving about $6.8 \mathrm{~g}$ potassium dihydrogen orthophosphate (pH-3.2)in $1000 \mathrm{~mL}$ double distilled water.

Mobile phase preparation: Phosphate buffer (pH-3.2): acetonitrile mixing in ratio of $40: 60 \% \mathrm{v} / \mathrm{v}$. Before use the mobile phase was filtered through $0.45 \mu \mathrm{m}$ Nylon- 6,6 membrane filter followed by $5 \mathrm{~min}$ of sonication.

Preparation of standard Stock solution: The standard stock solution of APR was prepared by weighed about $10 \mathrm{mg}$ APR in $10 \mathrm{ml}$ volumetric flask and dissolving in Diluent and make up the mark with diluent. Further, dilute $1 \mathrm{~mL}$ of standard stock solution in $10 \mathrm{~mL}$ volumetric flask and volume was made up to mark with diluent.

Method Validation: The developed method was validated by different parameters like specificity, linearity, precision, accuracy, ruggedness, robustness, LOD and LOQ as per ICH Q2 (R3) guidelines [7-9, 12]

Specificity: Specificity is the ability to assess unequivocally the analyte in the presence of components which may be expected to be present [8]. Typically these might include impurities, degradants, matrix etc. Specificity was estimated by injecting the APR standard solution, sample solution and blank.

Linearity: The linearity of an analytical procedure is its ability (within given range) to obtain test results which are directly proportional to the concentration (amount) of analyte in the sample. A graph of peak area versus concentration was plotted.

Linearity was prepared at 6 independent levels from 50$400 \mu \mathrm{g} / \mathrm{mL}$.

Precision: The precision of an analytical procedure expresses the closeness of agreement (degree of scatter) between the series of measurements obtained from multiple sampling of the same homogeneous sample under the prescribed conditions ${ }^{[7]}$
- REPEATABILITY: Repeatability expresses the precision under the same operating conditions over a short interval of time. Repeatability is also termed intraassay precision [7]. It was performed at 6 levels of same target concentration $(300 \mu \mathrm{g} / \mathrm{mL})$ with different standard stock solution $(500 \mu \mathrm{g} / \mathrm{mL})$.

Intermediate precision: (within laboratory variation) Different days/Different equipment.

- INTRADAY PRECISION: Intraday precision can be define as within day precision .It was performed at 3 levels of 3 different concentration $(50,100,150 \mu \mathrm{g} / \mathrm{mL})$ of APR within a day from standard stock solution (500 $\mu \mathrm{g} / \mathrm{mL})$.

- INTER-DAY PRECISION: Inter-day precision can be define as within a day precision. It was performed at 3 levels of 3 different concentration $(50,100,150 \mu \mathrm{g} / \mathrm{mL})$ of APR on different day from same standard stock solution $(500 \mu \mathrm{g} / \mathrm{mL})$.

Accuracy: The accuracy of analytical procedure expresses the closeness of agreement between the value which is accepted either as a conventional true value or an accepted reference value and the value found. This is sometimes termed trueness [7]. Accuracy of method was performed at $100 \mu \mathrm{g} / \mathrm{mL}$ in triplicate at $80 \%, 100 \%$ and $120 \%$ by standard addition method.

LOD: The limit of detection is determine by the individual analytical procedure of samples with known concentration of drug and by establishing the lowest level of analyte in a sample which can be detected, but not necessarily quantitated the specific value.

The Actual lowest concentration of analyte in sample detected is compared with blank result and which is based on standard deviation of the response and the slope [7].

\section{LOD $=3.3 \sigma / S$}

Where, $\mathrm{S}=$ the slope of calibration curve $\sigma=$ the standard deviation of the response

LOQ: The limit of quantitation is determined by the individual analytical procedure of samples and establishing the lowest amount of analyte in a sample, which can be determined with appropriate precision and accuracy [7].

\section{LOQ $=10 \sigma / S$}

Where, $\mathrm{S}=$ the standard deviation of response $\sigma=$ Mean of slopes of the calibration curves

Robustness: The robustness of an analytical procedure is an estimation of its capacity to remain unaffected by small, but deliberate variations in method parameters.

- Flow rate

- Concentration of acetonitrile

Ruggedness: The ruggedness is an analytical method of the degree of reproducibility of samples results obtained by analysis of the same samples under a different conditions for example in different $\mathrm{pH}$, different temperature and different mobile composition [7-8].

Degradation Study: Degradation study was carried out in acidic, alkali, oxidative condition. The standard Stock solution for forced degradation study $1000 \mu \mathrm{g} / \mathrm{mL}$ of APR 
was prepared. Kinetic study of Apremilast was performed to determine the order of degradation kinetic under different stress condition [11].

\section{Acidic Degradation:}

From the standard stock solution $3 \mathrm{~mL}$ was taken in a $10-\mathrm{mL}$ volumetric flask. Further $0.5 \mathrm{~mL}$ of $0.05 \mathrm{~N} \mathrm{HCl}$ was added in the flask. The mixture was kept at room temperature for 20 min. Solution was neutralized with $0.5 \mathrm{~mL}$ of $0.05 \mathrm{~N} \mathrm{NaOH}$ and the volume was made up to mark with diluent to achieve the concentration of $300 \mu \mathrm{g} / \mathrm{mL}$. Solution was then filtered with $0.45-\mu \mathrm{m}$ Nylon syringe filter and injected in the system.

\section{Alkaline Degradation:}

From the standard stock solution $3 \mathrm{~mL}$ was taken in a $10-\mathrm{mL}$ volumetric flask. Further $0.5 \mathrm{~mL}$ of $0.05 \mathrm{~N} \mathrm{NaOH}$ was added in the flask. The mixture was kept at room temperature for 20 min. Solution was neutralized with $0.5 \mathrm{~mL}$ of $0.05 \mathrm{~N} \mathrm{HCl}$ and the volume was made up to the mark with diluent to achieve the concentration of $300 \mu \mathrm{g} / \mathrm{mL}$. Solution was then filtered with 0.45

$\mu \mathrm{m}$ Nylon syringe filter and injected in the system.

\section{Oxidative Degradation:}

From the standard stock solution $3 \mathrm{~mL}$ was taken in a $10-\mathrm{mL}$ volumetric flask. Further $1 \mathrm{~mL}$ of $0.2 \%$ Hydrogen peroxide was added in the flask and the volume was made up to the mark with diluent to achieve the concentration of $300 \mu \mathrm{g} /$ $\mathrm{mL}$. Solution was then filtered with $0.45-\mu \mathrm{m}$ Nylon syringe filter and injected in the system.

\section{Photolytic Degradation:}

Photolytic degradation about $10 \mathrm{mg}$ of bulk drug was weighed and added in the Petri dish. Petri dish exposed to 5382 LUX and $144 \mathrm{UW} / \mathrm{cm} 2$ for 10 days. Degradation samples were subjected to analysis after suitable dilutions with diluent

\section{Degradation Kinetics Study:}

The Degradation kinetic study was done in alkaline condition. The conditions selected for the kinetic study was $0.05 \mathrm{~N}$ and $0.1 \mathrm{~N}$ of $\mathrm{NaOH}$ at $30^{\circ} \mathrm{C}$ and $50^{\circ} \mathrm{C}$.Then $0.5 \mathrm{~mL}$ Stock solutionin $10 \mathrm{~mL}$ volumetric flask and $2 \mathrm{~mL}$ of $0.05 \mathrm{~N}$ and $0.1 \mathrm{~N} \mathrm{NaOH}$ was further added to the flask. The solution was subjected to two different conditions at $30^{\circ} \mathrm{C}$ and $50^{\circ} \mathrm{C}$. The solution was neutralized with $0.5 \mathrm{~mL}$ of $0.05 \mathrm{~N}$ and $0.1 \mathrm{~N} \mathrm{HCl}$ respectively and made up to mark with diluent and make the concentration $300 \mu \mathrm{g} / \mathrm{mL}$. Solution was filtered with $0.45-\mu \mathrm{m}$ Nylon syringe filter and injected in the system. Percentage degradation of APR was estimated at above mentioned conditions.

\section{RESULT AND DISCUSSION:}

\section{Specificity:}

The specificity of the analytical method of APR is established by injecting the sample solution into the HPLC System.

- Diluent solution is used as blank (methanol)

- Standard solution of APR( $100 \mu \mathrm{g} / \mathrm{mL})$

- Test solution(APR marketed formulation)

The specificity data of APR mention in table 2.

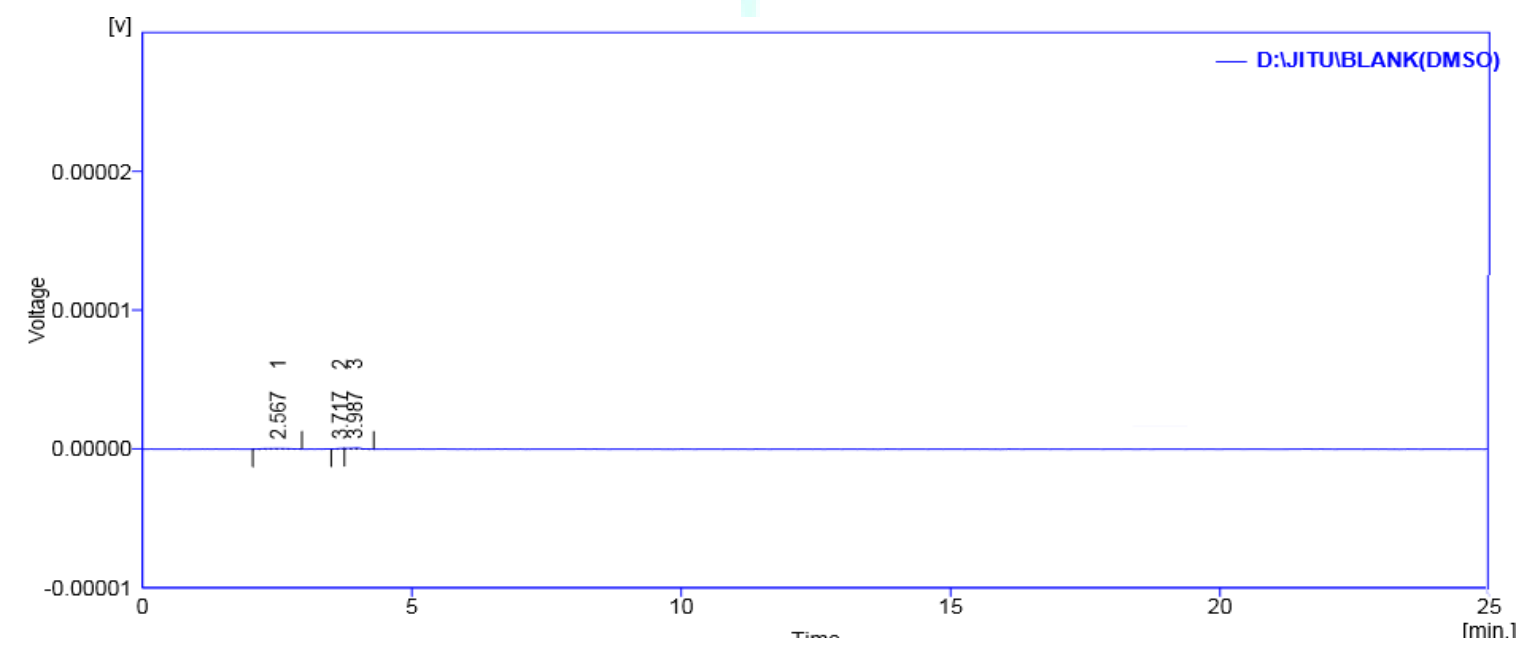

Figure.2 Chromatogram of blank methanol



Chromatograph of standard APR 


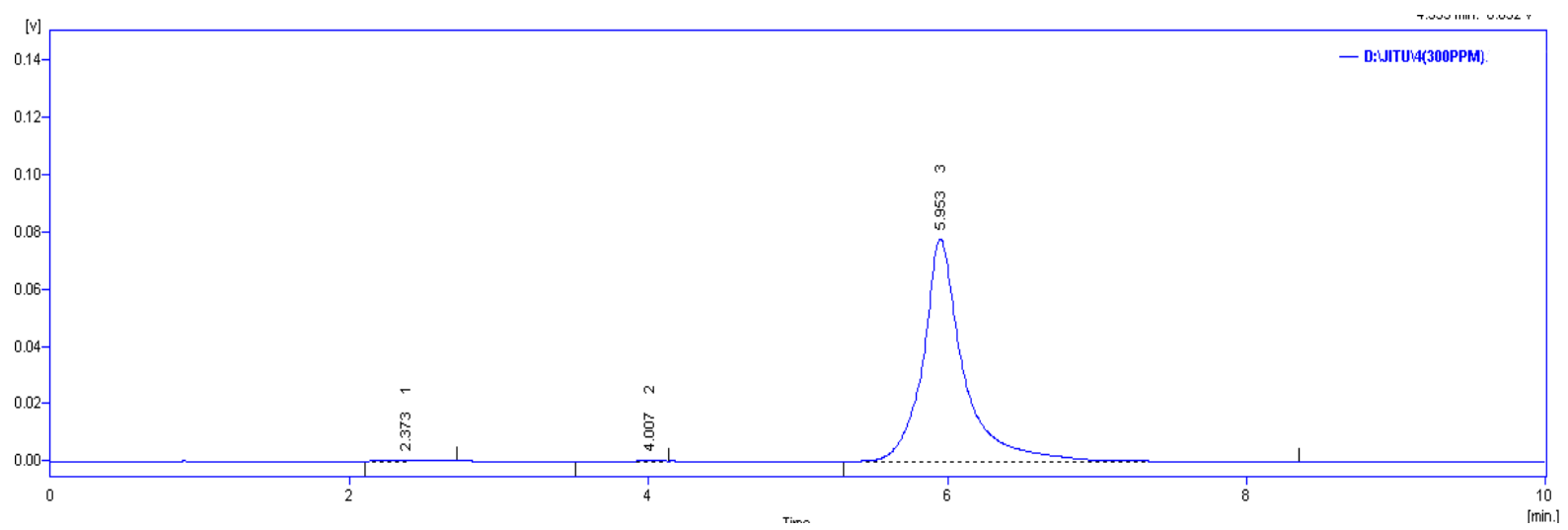

Figure.4 chromatograph of Test solution APR Table: 2 Specificity data of APR

\begin{tabular}{|c|l|l|c|}
\hline Sr. no. & Sample Name & Drug Name & Specificity \\
\hline 1 & Blank & No Peak & - \\
\hline 2 & Standard & APR & Specific \\
\hline 3 & Test & APR & Specific \\
\hline
\end{tabular}

\section{System Suitability:}

The prepared $100 \mu \mathrm{g} / \mathrm{mL}$ standard solution of APR was measured for parameters like retention time (RT), Theoretical plate and Tailing Factor by injecting the solution at three replicate level. Below mentioned values are within acceptable limit of chromatographic condition. The system suitability data of APR mention in table3.

Table: 3 System Suitability data of APR

\begin{tabular}{|c|c|c|}
\hline Parameters & Mean(n=3) & \%RSD \\
\hline RT(min) & 5.41 & 1.51 \\
\hline Theoretical plate & 4958.67 & 1.68 \\
\hline Tailing factor & 1.306 & 0.93 \\
\hline
\end{tabular}

\section{Linearity:}

The calibration curve of APR is linear in the concentration range of $50-400 \mu \mathrm{g} / \mathrm{mL}$. The regression data analysis of RPHPLC method is mention in table 4.

Table: 4 linearity data of APR

\begin{tabular}{|c|c|c|}
\hline Concentration $(\boldsymbol{\mu g} / \mathbf{m L})$ & $\begin{array}{c}\text { Area(mv) } \\
\text { Mean(n=6) }\end{array}$ & \%RSD \\
\hline 50 & 393.844 & 0.45 \\
\hline 100 & 806.067 & 0.69 \\
\hline 200 & 1633.766 & 0.47 \\
\hline 300 & 2408.507 & 0.33 \\
\hline 400 & 3207.949 & 0.42 \\
\hline
\end{tabular}

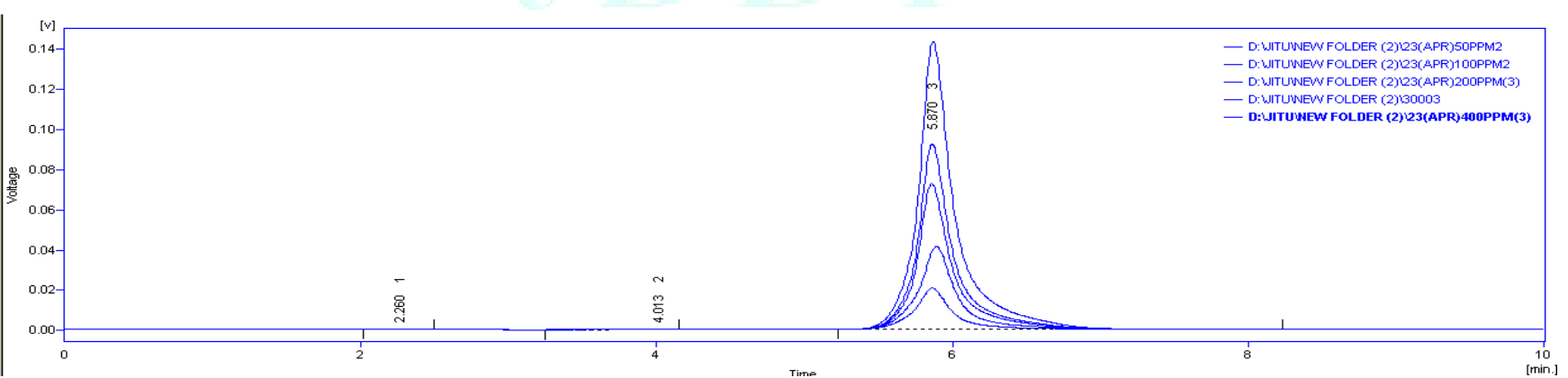

Figure: 5 chromatograph of APR Linearity Conc. $(\mu \mathrm{g} / \mathrm{mL})$ 


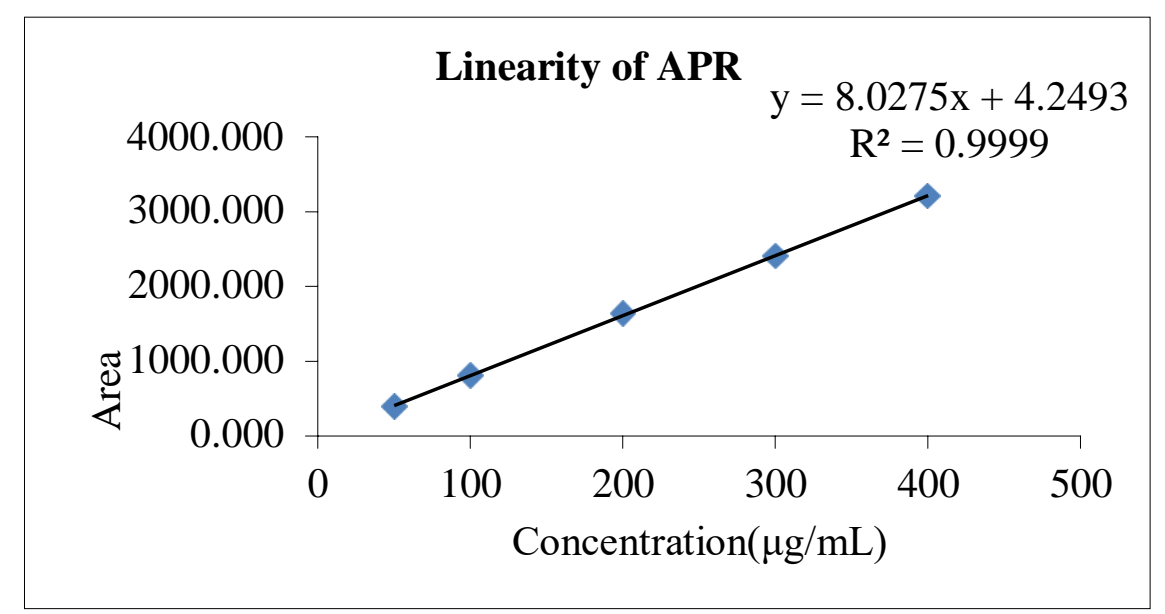

Figure: 6 Calibration curve of APR Table: 5 Regression data analysis RP-HPLC

\begin{tabular}{|l|l|}
\hline Parameter & APR \\
\hline Wavelength & $360 \mathrm{~nm}$ \\
\hline Range & $50-400 \mu \mathrm{g} / \mathrm{mL}$ \\
\hline Regression Equation & $\mathrm{Y}=8.0275 \mathrm{x}+4.2493$ \\
\hline Slop $(\mathrm{m})$ & 8.0275 \\
\hline Intercept(c) & 4.249 \\
\hline Correlation coefficient & 0.9999 \\
\hline
\end{tabular}

\section{Precision:}

Precision of analytical method was estimated by Repeatability, intraday precision and inter day precision of the APR standard solution. The Repeatability \%RSD was 0.77 and intraday precision \%RSD was 0.92 and that of inter day precision was 1.25 . The results of repeatability data, intraday and interday precision data of APR are shown in table 6, table 7 and table 8 respectively.

Table: 6 Repeatability data of APR

\begin{tabular}{|c|c|}
\hline \multicolumn{2}{|c|}{ Repeatability( 100 $\boldsymbol{\mu g} / \mathbf{m L})$} \\
\hline Replicates & Area \\
\hline $\mathbf{1}$ & 804.56 \\
\hline $\mathbf{2}$ & 796.31 \\
\hline $\mathbf{3}$ & 810.72 \\
\hline $\mathbf{4}$ & 802.2 \\
\hline $\mathbf{5}$ & 794.32 \\
\hline $\mathbf{6}$ & 806.3 \\
\hline mean & 802 \\
\hline \%RSD & 0.77 \\
\hline
\end{tabular}

Table: 7 Intraday Precision data of APR

\begin{tabular}{|c|c|c|}
\hline Concentration $(\boldsymbol{\mu g} / \mathbf{m L})$ & Average area (n=3) & \%RSD \\
\hline 50 & 394.74 & 0.49 \\
\hline 100 & 803.77 & 0.92 \\
\hline 300 & 2433.62 & 0.42 \\
\hline
\end{tabular}

Table: 8 Interday Precision data of APR

\begin{tabular}{|c|c|c|}
\hline Concentration $(\boldsymbol{\mu g} / \mathbf{m L})$ & Average area $(\mathbf{n}=3)$ & \%RSD \\
\hline 50 & 394.04 & 0.83 \\
\hline 100 & 801.39 & 1.25 \\
\hline 300 & 2479.05 & 1.20 \\
\hline
\end{tabular}

\section{Accuracy:}

Accuracy was calculated by performing the recovery study. A standard known quantity of APR was added into aliquots of sample solutions at the three different levels in $80 \%, 100 \%$, $120 \%$ and then diluted with the solvent. The percentage recovery obtained in range $99.71 \%, 99.48 \%$, and $99.86 \%$ respectively as mention in table 9. 
Table: 9 Accuracy data of APR $(n=3)$

\begin{tabular}{|c|c|c|c|c|}
\hline $\begin{array}{l}\text { Spiked } \\
\text { level }\end{array}$ & $\begin{array}{l}\text { Conc present in } \\
\text { mixture }(\mu \mathrm{g} / \mathrm{mL})\end{array}$ & $\begin{array}{c}\text { Conc added } \\
(\mu \mathrm{g} / \mathrm{mL})\end{array}$ & $\begin{array}{c}\text { Conc recovered } \\
((\mu \mathrm{g} / \mathrm{mL})\end{array}$ & $\begin{array}{c}\text { \%Recovery } \\
\pm \text { SD }\end{array}$ \\
\hline $80 \%$ & 100 & 80 & 179.54 & \multirow{3}{*}{$99.71 \pm 0.37$} \\
\hline $80 \%$ & 100 & 80 & 178.79 & \\
\hline $80 \%$ & 100 & 80 & 180.13 & \\
\hline $100 \%$ & 100 & 100 & 200.08 & \multirow{3}{*}{$99.48 \pm 0.51$} \\
\hline $100 \%$ & 100 & 100 & 198.72 & \\
\hline $100 \%$ & 100 & 100 & 198.09 & \\
\hline $120 \%$ & 100 & 120 & 221.13 & \multirow{3}{*}{$99.86 \pm 0.59$} \\
\hline $120 \%$ & 100 & 120 & 219.26 & \\
\hline $120 \%$ & 100 & 120 & 218.64 & \\
\hline
\end{tabular}

\section{Limit of Detection and Limit of Quantification:}

Limit of Detection was 0.04 and the Limit of Quantification was 0.13 was calculated.

\section{Robustness:}

The developed method was found to be robust when changes were made in parameters as mentioned in table like change in mobile phase, change in flow rate, and change in $\mathrm{pH}$. Average peak area and \%RSD was noted. The Robustness data of APR mention in table 10.

\section{Assay of Marketed formulation:}

The assay was estimated by taking twenty tablets of APR weighted and crushed. The solution was prepared by weighed $10 \mathrm{mg}$ APR in $10 \mathrm{~mL}$ volumetric flask and making volume up to the mark with diluent. From stock solution take $1 \mathrm{~mL}$ in $10 \mathrm{~mL}$ volumetric flask and making volume up to mark with diluent. The Assay result of APR mention in table 11.

Table: 10 Robustness data of APR ( $n=3)$

\begin{tabular}{|l|c|c|c|}
\hline Factor & Level of change & $\begin{array}{c}\text { Average peak } \\
\text { Area }\end{array}$ & \%RSD \\
\hline \multirow{3}{*}{ Kobile phase } & $\mathrm{KH} 2 \mathrm{PO} 4: \mathrm{ACN}=58: 42$ & 779.7 & 0.72 \\
\cline { 2 - 4 } & $\mathrm{KH} 2 \mathrm{PO} 4: \mathrm{ACN}=60: 40$ & 777.9 & 0.46 \\
\cline { 2 - 4 } & $\mathrm{KH} 2 \mathrm{PO} 4: \mathrm{ACN}=56: 44$ & 778.3 & 0.52 \\
\hline \multirow{3}{*}{ Flow rate } & 0.8 & 776.2 & 0.51 \\
\cline { 2 - 4 } & 1 & 777.9 & 0.46 \\
\cline { 2 - 4 } & 1.2 & 777.7 & 0.45 \\
\hline
\end{tabular}


Table: 11 Assay data of APR

\begin{tabular}{|c|c|c|c|}
\hline Sr.No & Recovered (n=6) & fan \% Drug Recovered & $\begin{array}{l}\text { RSD of Drug } \\
\text { Recovered }\end{array}$ \\
\hline 1 & 99.14 & \multirow{6}{*}{99.78} & \multirow{6}{*}{0.68} \\
\hline 2 & 100.20 & & \\
\hline 3 & 99.90 & & \\
\hline 4 & 100.75 & & \\
\hline 5 & 99.91 & & \\
\hline 6 & 99.84 & & \\
\hline
\end{tabular}

Degradation Study: The degradation was observed in acidic condition (21\%) and in alkaline condition (6.5\%), in $0.2 \% \mathrm{v} / \mathrm{v}$ Hydrogen peroxide condition (25.7\%) and in photolysis degradation (3.9). Degradation behaviour in different condition mention in table 12.

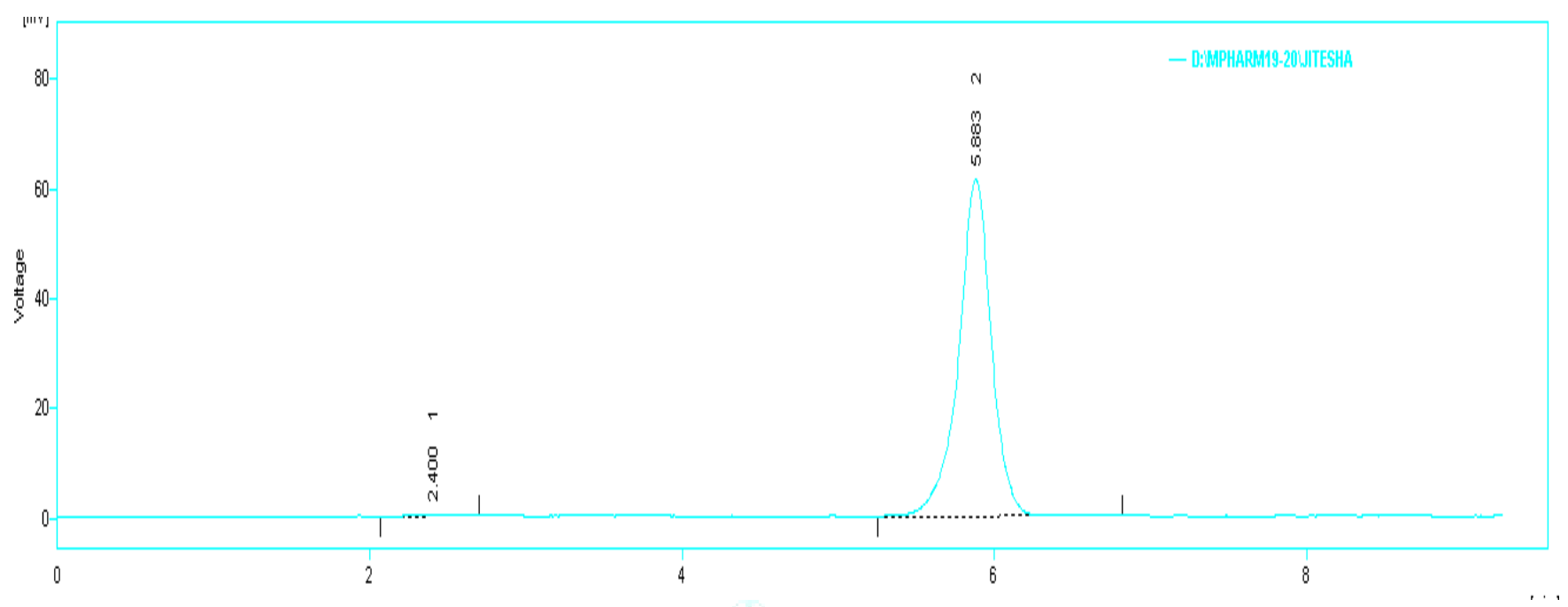

Figure: 7 Alkaline Degradation of APR

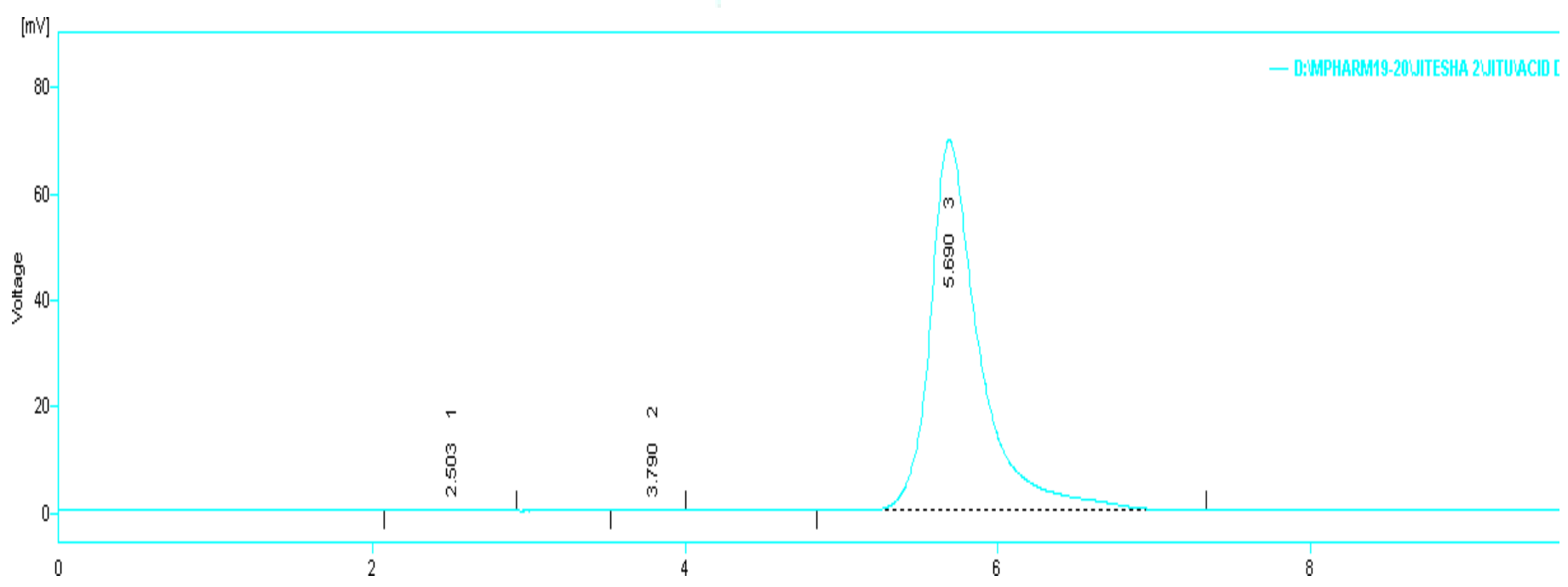

Figure: 8 Acidic Degradation of APR 


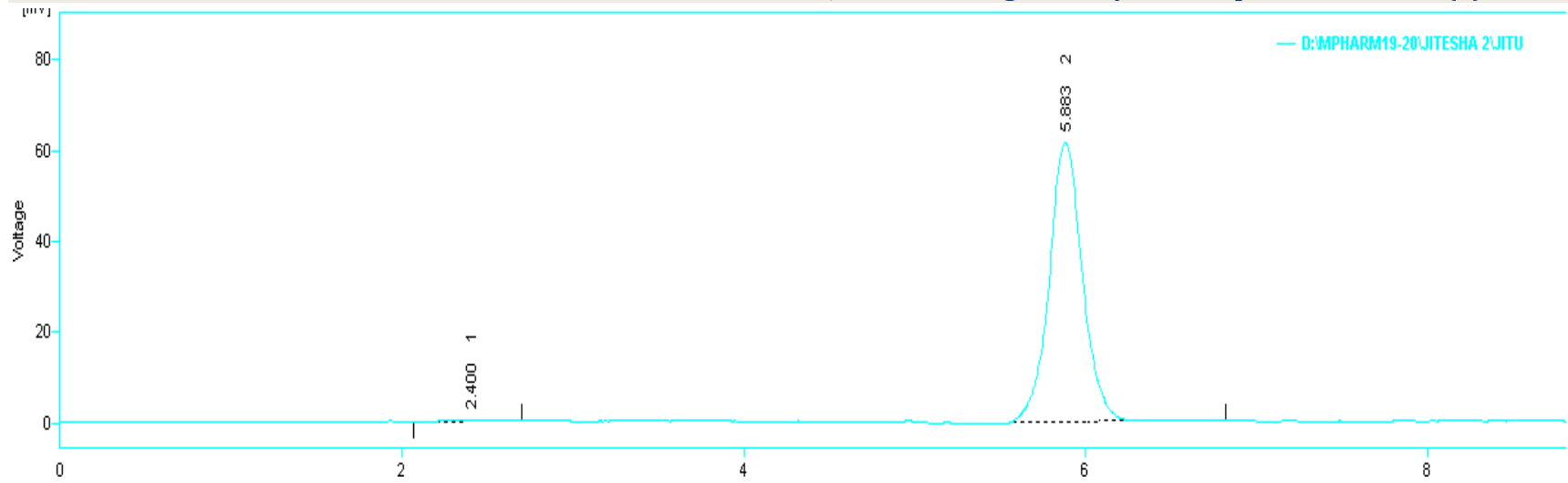

Figure: 9 oxidative Degradation of APR

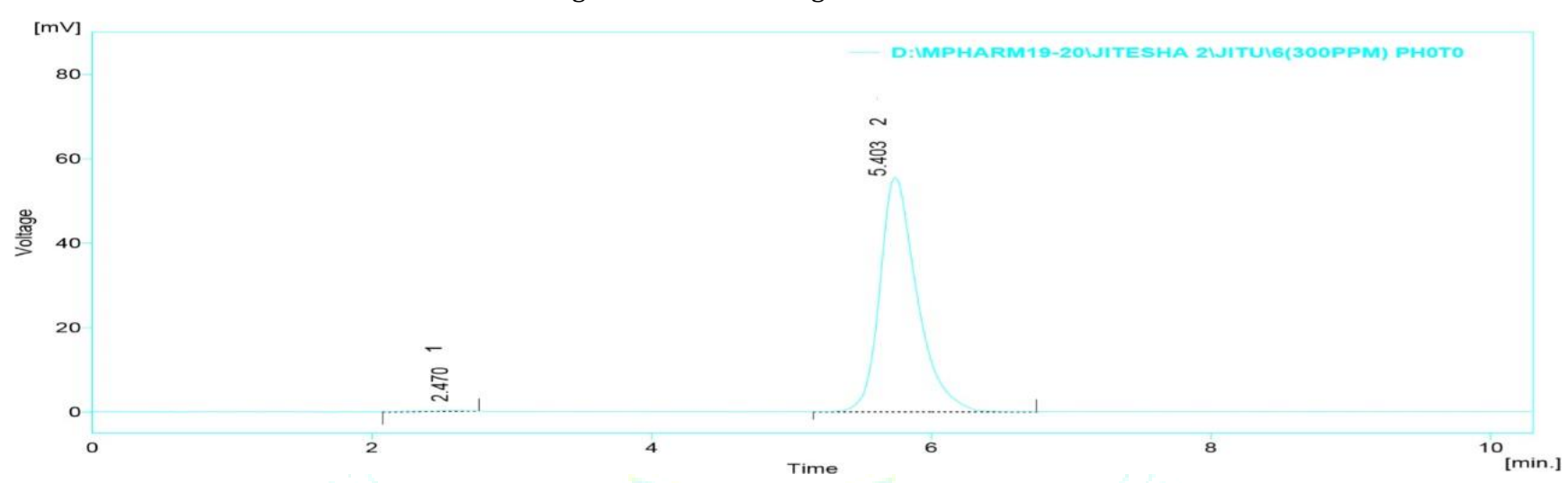

Figure: 10 Photolytic degradation Table: 12 Stability studies of APR

\begin{tabular}{|c|c|c|c|c|}
\hline $\begin{array}{c}\text { Degradation } \\
\text { Type }\end{array}$ & $\begin{array}{c}\text { Stress } \\
\text { condition }\end{array}$ & Time & \% Assay & $\begin{array}{c}\text { \% of Degradation } \\
\text { Product }\end{array}$ \\
\hline Control sample & As Such & - & 100 & - \\
\hline $\begin{array}{c}\text { Acidic } \\
\text { degradation }\end{array}$ & $\begin{array}{c}0.05 \mathrm{M} \mathrm{MeoH} \\
\mathrm{HCl}\end{array}$ & $20 \mathrm{~min}$ & 79 & 6.5 \\
\hline $\begin{array}{c}\text { Alkaline } \\
\text { degradation }\end{array}$ & $\begin{array}{c}0.05 \mathrm{M} \mathrm{MeoH} \\
\mathrm{NaOH}\end{array}$ & $20 \mathrm{~min}$ & 93.5 & 25.7 \\
\hline $\begin{array}{c}\text { Oxidative } \\
\text { degradation }\end{array}$ & $0.2 \% \mathrm{H} 2 \mathrm{O} 2$ & $20 \mathrm{~min}$ & 74.3 & 3.9 \\
\hline $\begin{array}{c}\text { Photolysis } \\
\text { degradation }\end{array}$ & $5382 \mathrm{LUX}$ and & 10 days & 96.1 & \\
\hline
\end{tabular}

\section{Degradation kinetic study:}

Degradation kinetic study of bulk drug in alkaline condition at $30^{\circ} \mathrm{C}$ and $50^{\circ} \mathrm{C}$ that result show that the decrease in area with increasing the time. The plots of zero order (\%drug remaining vs time), first order ( $\log c$ value vs time) and second order (1/log c vs time) were plotted individually. From the result obtain it was concluded that the $r^{2}$ value of first order appeared high as compared to the $r^{2}$ value of zero order and second order. So, alkali degradation of APR followed first order kinetic. The result of alkaline degradation kinetic study of APR mention in table 13.
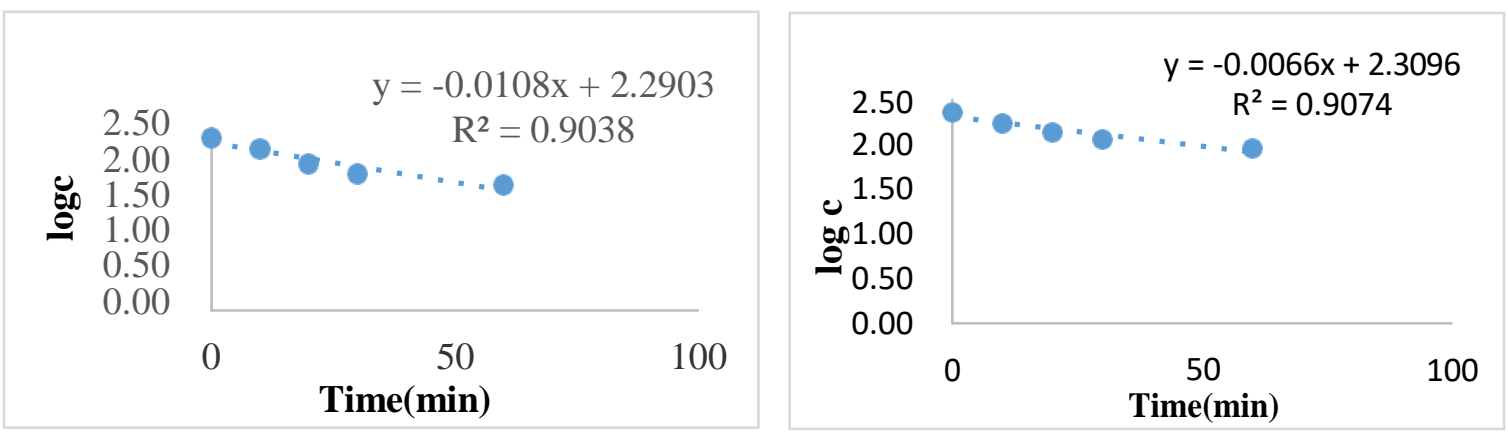

Figure: $11 \mathrm{Log} \mathrm{C}$ vs Time Graph for alkaline condition in $0.05 \mathrm{~N} \mathrm{NaOH}$ at $30^{\circ} \mathrm{C}$ (a) and $50^{\circ} \mathrm{C}$ (b) 




Figure: 12 Log C vs Time Graph for alkaline condition in $0.1 \mathrm{~N} \mathrm{NaOH}$ at $30^{\circ} \mathrm{C}$ (a) and $50^{\circ} \mathrm{C}$ (b) Table: 13 Degradation Kinetic study of APR in alkaline condition

Table: 13 Degradation Kinetic study of APR in alkaline condition

\begin{tabular}{|c|c|c|c|c|c|}
\hline As such & 2385.286 & \multicolumn{4}{|c|}{ Degradation kinetic study } \\
\hline $\begin{array}{c}\text { Target } \\
\text { conc }(\mu \mathrm{g} / \mathrm{mL})\end{array}$ & 300 & & & & \\
\hline $\begin{array}{c}\text { Degradation } \\
\text { condition }\end{array}$ & Temperature & Time(min) & \% Assay & $\begin{array}{c}\text { Degradation rate } \\
\text { constant } k\end{array}$ & $\mathrm{t}^{1 / 2(\min )}$ \\
\hline \multirow{10}{*}{$\begin{array}{r}0.05 \mathrm{~N} \\
\mathrm{NaOH}\end{array}$} & \multirow{5}{*}{$30^{\circ} \mathrm{C}$} & 0 & 77.15 & 0.000 & 0.00 \\
\hline & & 10 & 62.84 & 0.004 & 180.31 \\
\hline & & 20 & 47.82 & 0.009 & 75.36 \\
\hline & & 30 & 41.11 & 0.012 & 56.38 \\
\hline & & 60 & 28.96 & 0.020 & 34.93 \\
\hline & \multirow{5}{*}{$50^{\circ} \mathrm{C}$} & 0 & 77.15 & 0.000 & 0.00 \\
\hline & & 10 & 57.43 & 0.006 & 124.26 \\
\hline & & 20 & 37.35 & 0.014 & 48.45 \\
\hline & & 30 & 28.11 & 0.021 & 33.77 \\
\hline & & 60 & 17.23 & 0.032 & 21.51 \\
\hline \multirow{10}{*}{$0.1 \mathrm{~N} \mathrm{NaOH}$} & \multirow{5}{*}{$30^{\circ} \mathrm{C}$} & 0 & 71.05 & 0.000 & 0.00 \\
\hline & & 10 & 50.17 & 0.007 & 103.22 \\
\hline & & 20 & 30.61 & 0.017 & 40.55 \\
\hline & & 30 & 21.42 & 0.023 & 30.11 \\
\hline & & 60 & 14.13 & 0.036 & 19.33 \\
\hline & \multirow{5}{*}{$50^{\circ} \mathrm{C}$} & 0 & 71.05 & 0.000 & 0.00 \\
\hline & & 10 & 47.41 & 0.008 & 88.32 \\
\hline & & 20 & 25.60 & 0.021 & 32.81 \\
\hline & & 30 & 16.76 & 0.031 & 22.07 \\
\hline & & 60 & 10.52 & 0.044 & 15.73 \\
\hline
\end{tabular}

\section{CONCLUSION:}

The developed RP-HPLC method is simple, specific, accurate, precise and stability indicating which can be useful in routine analysis laboratories for the determination of APR in bulk drug and pharmaceutical formulation without any interference from excipient, impurity and degradation product. This method have been validated as per ICH guidelines, and it meets all the acceptance criteria given in ICH guidelines. Degradation kinetic study shows that APR follows first order kinetic in alkaline condition.

\section{REFERENCES:}

1. "FDA LABEL of apremilast" https://www.accessdata.fda.gov/drugsatfda_docs/label/2017 /205437s006lbl.pdf
2. Schafer P. Apremilast mechanism of action and application to psoriasis and psoriatic arthritis. Biochemical pharmacology. 2012 Jun 15; 83(12):1583-90.

3. Xiong K, Ma X, Cao N, Liu L, Sun L, Zou Q, Wei P. Identification, characterization and HPLC quantification of impurities in apremilast. Analytical Methods. 2016;8(8):1889-97.

4. Landge SB, Dahale SB, Jadhav SA, Solanki PV, Bembalkar SR, Mathad VT. Development and validation of stability indicating rapid RP-LC method for determination of process and degradation related impurities of Apremilast, an antiinflammatory drug. Am J Anal Chem. 2017 Jun 12; 8:380.

5. https://www.researchgate.net/figure/Chemical-structure-ofapremilast_fig1_331389543

6. Chaudhari SR, Shirkhedkar AA. Design of Experiment Avenue for development and validation of RP-HPLC-PDA method for 


\section{Patel et al}

determination of apremilast in bulk and in in-house tablet formulation. Journal of Analytical Science and Technology. 2019 Dec; 10(1):10. 8.https://www.gmp-

compliance.org/guidelines/gmp-guideline/ich-q2r1-

validation-of- analytical-procedures-text-and-methodology

7. Lonkar N, Sawant S, Dole M. Development and validation of stability indicating RP-HPLC method for the estimation of apremilast by forced degradation studies. W. J Pharm Pharm Sci. 2017a. 2017; 6:1493-502

8. Badhe P, Aher S, Saudagar RB. Analytical Method of Apremilast: A Review. Journal of Drug Delivery and Therapeutics. 2019 Jun 29; 9(3-s):1116-9.

9. Bhole RP, Naksakhare SR, Bonde CG. A Stability Indicating HPTLC Method for Apremilast and Identification of degradation products using MS/MS. Journal of Pharmaceutical Sciences and Research. 2019 May 1; 11(5):1861-9.

10. Ravisankar P, Sulthana MS, Babu PS. Development and validation of stability-indicating UV spectrophotometric method for determination of Apremilast in bulk and pharmaceutical dosage form. Ind J Res Pharm Biotechnol. 2017; 5:47.

14.https://www.ema.europa.eu/en/documents/scientificguideline/ich-q-2-r1-validation- analytical-procedures-textmethodology-step-5_en.pdf
Journal of Drug Delivery \& Therapeutics. 2020; 10(2):76-85

11. Papp K, Cather JC, Rosoph L, Sofen H, Langley RG, Matheson RT, Hu C, Day RM. Efficacy of apremilast in the treatment of moderate to severe psoriasis: a randomised controlled trial. The Lancet. 2012 Aug 25; 380(9843):738-46.

12. Pandya CP, Rajput SJ.Stress Degradation Studies of Anagliptin, Development of Validated Stability Indicating Method, Degradation Kinetics Study, Identification and Isolation of Degradation Products. Chromatographia. 2018 Nov 1; 81(11):1533-50.

13. Pandya CP, Rajput SJ. Stress Degradation Studies of Riociguat, Development of Validated Stability Indicating Method, Identification, Isolation and Characterization of Degradation Products by LC-HR-MS/MS and NMR Studies. Indian Journal OfPharmaceutical Education And Research. 2019 0ct 1; 53(4):S630-41.

14. Bockhorn H, Hornung A, Hornung U, Schawaller D. Kinetic study on the thermal degradation of polypropylene and polyethylene. Journal of Analytical and Applied Pyrolysis. 1999 Jan 1; 48(2):93-109.

15. SHRIMALI C, BAGHEL M, RAJPUT S. Development and validation of stability indicating rp-hplc method of nepafenac and its degradation products: application to degradation kinetic. Int J Pharm Pharm Sci. 2014; 6(9):387-93. 